\title{
Colonisation of temporary macrophyte substratum by midges (Chironomidae: Diptera)
}

\author{
Dubravka Čerba ${ }^{1}$, Zlatko Mihaljević ${ }^{2 *}$ and Jasna Vidaković ${ }^{1}$ \\ 1 Department of Biology, Josip Juraj Strossmayer University, Trg Ljudevita Gaja 6, HR-31000 Osijek, Croatia \\ 2 Department of Zoology, Faculty of Science, University of Zagreb, Rooseveltov trg 6, HR-10000 Zagreb, Croatia
}

Received 2 February 2010; Accepted 18 May 2010

\begin{abstract}
This study investigates a phytophylous community of Chironomidae larvae on the submerged plant species Myriophyllum spicatum L. in a eutrophic lake (Lake Sakadaš, Danube floodplain area in Croatia) during summer 2004. This macrophyte species appeared for the first time in the lake in 2004, lasted approximately three months and was considered as a temporary habitat. The chironomid community was very abundant in the stands of this macrophyte species, which developed at three sites. The recorded species belong to three subfamilies: Chironominae (Chironomini and Tanytarsini), Orthocladiinae and Tanypodinae. Species composition varied in time, though Orthocladiinae with their representative Cricotopus sylvestris gr. dominated throughout the entire sampling period, accounting for approx. $60 \%$ of the total community. However, the presence of this species group experienced a marked drop to only $10 \%$ in September when Chironomini larvulae and Paratanytarsus sp. prevailed. Furthermore, the share of Endochironomus albipennis (Meigen 1830) in relation to other species was also consistently higher. NMDS ordination and cluster analysis separated three main colonization periods based on larval abundance. RDA analysis indicated the influence of environmental variables, especially Secchi depth, macrophyte dry weight, depth and water temperature, on chironomid community structure.
\end{abstract}

Key words: Chironomid larvae / floodplain lake / Myriophyllum spicatum / environmental conditions

\section{Introduction}

Chironomids are a very successful taxonomic group in fresh-waters, with high abundance, often present as the most abundant one (Wiederholm, 1983). They are very numerous and adaptable in both permanent and temporary habitats (Armitage et al., 1995; Frouz et al., 2003; Hamerlík and Brodersen, 2010). Being good colonizers chironomids are essential for the transport of nutrients in lakes and reservoirs (Dévai, 1990) and for early colonizers small size and short life cycle are important characteristics (Wotton et al., 1992). Chironomid communities in lakes can be used as climate change or water quality indicators (Brodersen et al., 2001; Bitušik et al., 2006; Langdon et al., 2006; Hamerlik and Bitušik, 2009). Chironomids feed on algae, detritus and associated microorganisms, macrophytes, wood debris, and other invertebrates of adequate size, and are prey for predatory larvae and fish, thus linking higher and lower trophic categories (Armitage et al., 1995; Dvorák, 1996; Nazarova et al., 2004).

\footnotetext{
*Corresponding author: zmihalj@biol.pmf.hr
}

Myriophyllum spicatum L. (Eurasian water milfoil) is a submerged macrophyte species with dissected leaves providing a suitable habitat for many invertebrate groups including chironomids (Soszka, 1975; Menzie, 1981; Balci and Kennedy, 2003). Chironomid larvae form a significant portion of the insect fauna on many aquatic macrophytes (Menzie, 1980; Balci and Kennedy, 2003), but colonisation and succession of chironomids on macrophytes has been generally ignored.

Phytophylous communities were studied in 2001, 2002 and 2004 (Bogut et al., 2007, 2009, 2010; Vidaković and Bogut, 2007; Cerba et al., 2009) in Conakut channel and Lake Sakadaš within the Kopački Rit Nature Park (a large Danube floodplain area). M. spicatum was recorded in Lake Sakadaš for the first time in 2004, despite being common in other floodplain waterbodies. Although the dominance of chironomids has been recorded in association with macrophytes (Bogut et al., 2007, 2009; Čerba et al., 2009), there is no information on the diversity of Chironomidae larvae in this area. Research on the family Chironomidae in Croatia has primarily been concentrated on lotic ecosystems (Tavčar, 1988; Mihaljević et al., 1998). 


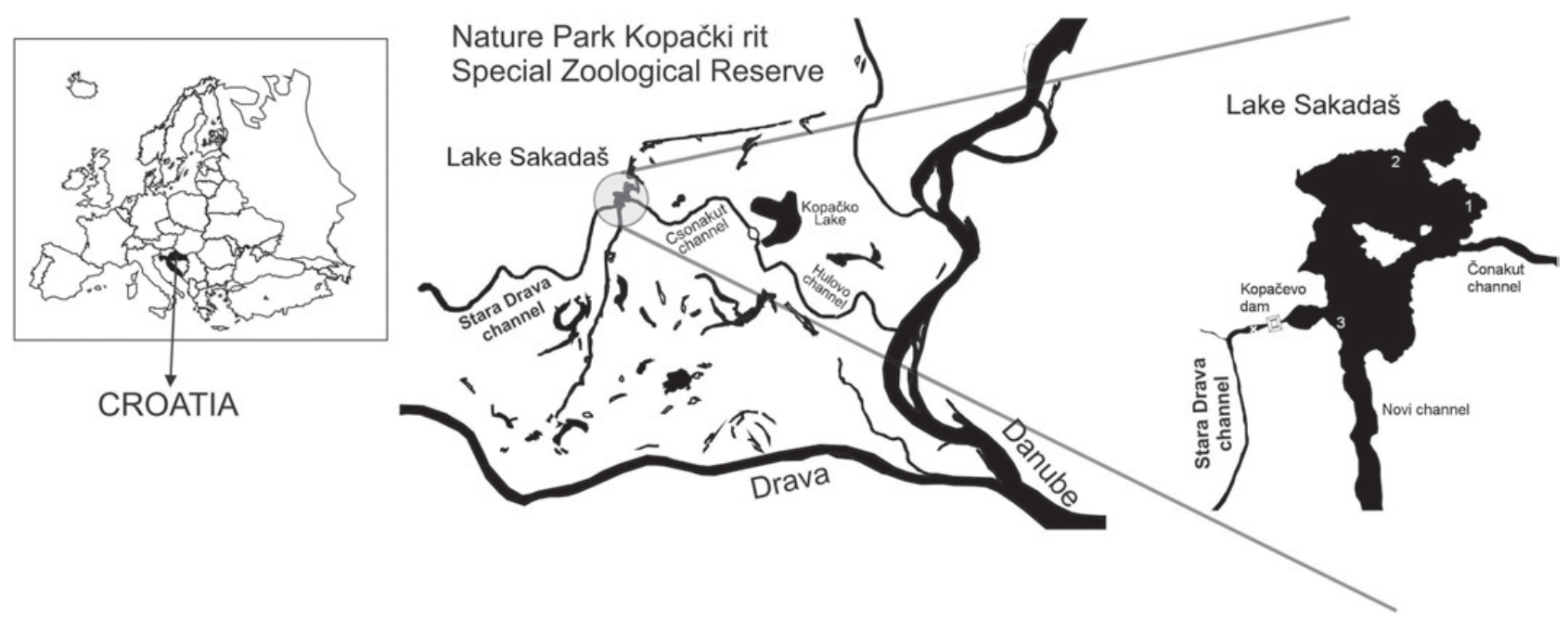

Fig. 1. Floodplain area of Kopački Rit Nature Park and sampling stations (1, 2 and 3) in Lake Sakadaš.

There is some information concerning lakes and reservoirs, though these relate to karstic lakes and man-made reservoirs located in areas of Croatia having a Mediterranean climate (Tavčar, 1993; Mihaljević et al., 2000, 2004). Furthermore, the majority of data are confined to unpublished environmental studies.

The objective of this study was to establish the composition and abundance of chironomid species, colonisation dynamics and temporal changes in chironomid community structure, and the influence of environmental variables on the phytophylous chironomid community.

\section{Materials and methods}

\section{Study area}

This study was carried out in a floodplain lake, Lake Sakadaš within Kopački Rit Nature Park. The park lies in northeastern Croatia within the Pannonian biogeographic region, and represents one of the Danube's largest floodplains. This area is a very important nesting area for a great variety of birds (and as such is included on the list of Important Bird Areas) and is also a habitat for diverse and numerous invertebrate and vertebrate fauna. Kopački Rit was included on the RAMSAR List of Wetlands of International Importance in 1993 (RAMSAR, 2005). The protected floodplain area is located between 1383 and $1410 \mathrm{rkm}$ of the Danube, with a surface of $177 \mathrm{~km}^{2}$ and is under the influence of the Danube hydrodynamic regime. The influence of limno- and potamophase on the floodplain biocenosis can be seen at different trophic levels phytoplankton, bacteria and periphyton (Palijan and Fuks, 2006; Mihaljević et al., 2009; Vidaković et al., to appear). The flooding in 2004 started at the end of March and lasted till the beginning of August (average amplitude was $1.3 \mathrm{~m}$, and total duration 131 days) (Peršić et al., to appear). From the beginning of July towards the end of September Danube water level was gradually decreasing with some exception to the last few days of July. Lake
Sakadaš is connected to the parent river via the Čonakut and Hulovo channels (Fig. 1). At the western side of the lake is a dam connecting the lake with the collecting channel. The lake has a dendritic shape, covers an area of approximately 6 ha and has an average depth of $7 \mathrm{~m}$. According to monitoring data collected between November 1997 and June 2004 (project: Protection of the Kopacki Rit Water Bodies; Ministry of Science, Education and Sports) and Vidaković and Bogut (2007), no macrophytes were recorded in Lake Sakadaš. Since 2004, different macrophyte types have formed microhabitat patches in the lake. M. spicatum and Ceratophyllum demersum L. represent submerged macrophytes. There were also free-floating Spirodella sp. and Nymphoides peltata (S. G. Gmel.) O. Kuntze. The amphibious species Polygonum amphibium All. was recorded sporadically, in addition to the free-floating Lemna sp., Trapa natans L. and Potamageton gramineus L. Three sites in the eastern, northeastern and southwestern shallower part of the lake, where large stands of $M$. spicatum developed, were selected as study stations (Fig. 1).

\section{Environmental conditions}

Chemical and physical variables, i.e. temperature and dissolved oxygen, were measured weekly in situ $(10 \mathrm{~cm}$ below the water surface) with the WTW Multi 340i set. Transparency was measured using the Secch disc and methods assigned by APHA (1985) regulations were used to analyse concentrations of chlorophyll $a$ (Chl $a)$ and total phosphorus (TP). Trophic state indices (TSITP and TSIChl $a$ ) were determined according to Carlson and Simpson (1996).

\section{Sampling strategy}

Triplicate samples (each replicate included a single plant) within every macrophyte stand, were taken from 
a boat on a weekly basis (from 14 July to 8 September 2004) with a plastic hand cylinder $(43 \mathrm{~cm}$ tall, $10 \mathrm{~cm}$ in diameter). The stand at station 1 lasted for four weeks from the beginning of research period (until 4 August). The stand at station 2 lasted until 12 August and at station 3 for the duration of the sampling period (until 8 September). Sampling was carried out when the macrophyte reached and sustained a suitable size for sampling from the boat. After 8 September, with the end of the vegetation season, the stands sank to the bottom and sampling could no longer be carried out. In the laboratory, invertebrates were dislodged from the plant and rinsed through a sieve with $60 \mu \mathrm{m}$ mesh. Preserving solution was made of $585 \mathrm{~mL} 96 \%$ ethanol, $310 \mathrm{~mL} \mathrm{H}_{2} \mathrm{O}, 100 \mathrm{~mL} \mathrm{4 \%}$ formaldehyde and $5 \mathrm{~mL}$ glycerine. To determine macrophyte dry biomass, plants were dried for $24 \mathrm{~h}$ at $60^{\circ} \mathrm{C}$ (Hann, 1995).

\section{Chironomidae larvae samples}

Chironomid larvae were counted and separated under the stereoscopic microscope Olympus SZX9. In samples with more than 100 individuals, 100 were randomly picked for determination while in samples with less than 100 individuals, all individuals were determined. Separated individuals were prepared for mounting according to Punti et al. (2007) and identified to the genus and species level under an Olympus BX51 microscope. Chironomid larvae were identified using the following taxonomic keys: Cranston (1982), Wiederholm (1983), Schmid (1993), Rieradevall and Brooks (2001), and Brooks et al. (2007). Individuals that were large enough to mount on slides but still too small for a better determination are listed as Chironomidae indet. in Table 1. Undeterminable larvulae stages of the tribe Chironomini are referred as Chironomini Gen. sp. (Table 1). For algal determination Streble and Krauter (2002) was used.

\section{Statistical analysis}

Chironomid abundance is presented as the number of individuals per $100 \mathrm{~g}$ of plant dry weight, percentage contribution and total density. For multivariate statistic analysis, the PRIMER 6 software package was used (Clarke and Gorley, 2006). Based on chironomid abundance data (fourth root transformed), cluster analysis and non-metric multi dimensional scaling (NMDS) were applied on the Bray-Curtis similarity matrix. The contribution of species abundance to the similarity within defined groups and dissimilarities between groups was investigated using the SIMPER procedure. The ANOSIM permutation test showed the level of significance of differences in the chironomid community structure between data groups (colonization periods) defined by cluster analysis and NMDS. Redundancy analysis (RDA) was used to demonstrate the importance of different environmental variables in determining the structure of chironomid assemblages $(\log (x+1)$ transformed abundance data), using CANOCO 4.5 (ter Braak and Šmilauer, 2002).

\section{Results \\ Environmental conditions}

The environmental variables are given in Table 2 . Depth in the sampled sites varied between $0.23 \mathrm{~m}$ and $3.74 \mathrm{~m}$, while water depth of the lake decreased during the sampling season because of evaporation and low precipitation. Oxygen concentrations were low in July but did not fall below $2 \mathrm{mg} . \mathrm{L}^{-1}$, which would indicate anoxic conditions. At the end of the vegetation season, greater macrophyte biomass and higher $\mathrm{Chl} a$ concentration was recorded. There was a decrease in Chl $a$ concentration on 21 July in all the stations. Trophic state indices based on TP and Chl $a$ concentrations indicated eutrophy with a tendency towards hypertrophy in Lake Sakadaš: TSITP varied from 35.8 to 105.8 and TSIChl $a$ from 51.7 to 70.4 (Table 2).

\section{Chironomidae community}

The larvae in Lake Sakadaš belong to three Chironomidae subfamilies: Chironominae (tribes Chironomini and Tanytarsini), Orthocladiinae and Tanypodinae. Members of the subfamily Orthocladiinae are Corynoneura sp., Cricotopus sylvestris gr., Cricotopus/Orthocladius and Psectrocladius sordidellus gr. while Chironomini are represented with five genera (Table 1). Although the most diverse, the Chironominae subfamily with a total abundance of 147322 ind./100 g d.w. throughout the sampling period was not the most abundant $(24.53 \%)$. Orthocladiinae midges dominated the samples, comprising in total 400262 ind. $/ 100 \mathrm{~g} \mathrm{~d}$.w. or $66.63 \%$, while Tanypodinae contributed less than $1 \%$ with 195 ind. $/ 100 \mathrm{~g} \mathrm{d.w.}$ Cricotopus $(65.07 \%)$ was the most abundant genus followed by Endochironomus (12.53\%) and Paratanytarsus $(6.13 \%)$ (Table 1$)$. At the beginning of the sampling period (July), large numbers of $C$. sylvestris gr. were present. The highest abundance of $C$. sylvestris gr. was recorded on 21 July at stations 2 and 3 while at station 1 the highest abundance was found on 14 July. The share of this species group decreased considerably in September, from approx. $60 \%$ to $10 \%$. Meanwhile, there was a substantial increase of the share of Chironomini larvulae (Chironomini Gen. sp.). For Chironomini larvulae, the highest abundances were recorded on 14 July (station 2) and 1 September (station 3). E. albipennis had the highest abundance 14 July (station 1) and 21 July (stations 2 and 3). This species was always present throughout the research period, especially in July (Table 1). Two Orthocladiinae species were recorded only at station 3: Corynoneura sp. on 28 July and P. sordidellus gr. on 18 August. Endochironomus tendens (Fabricius 1775) was found only on 18 August at station 3, 
Table 1. Chironomid larvae species composition with absolute and relative abundance expressed as percentage contribution and total density* in Lake Sakadaš in 2004.

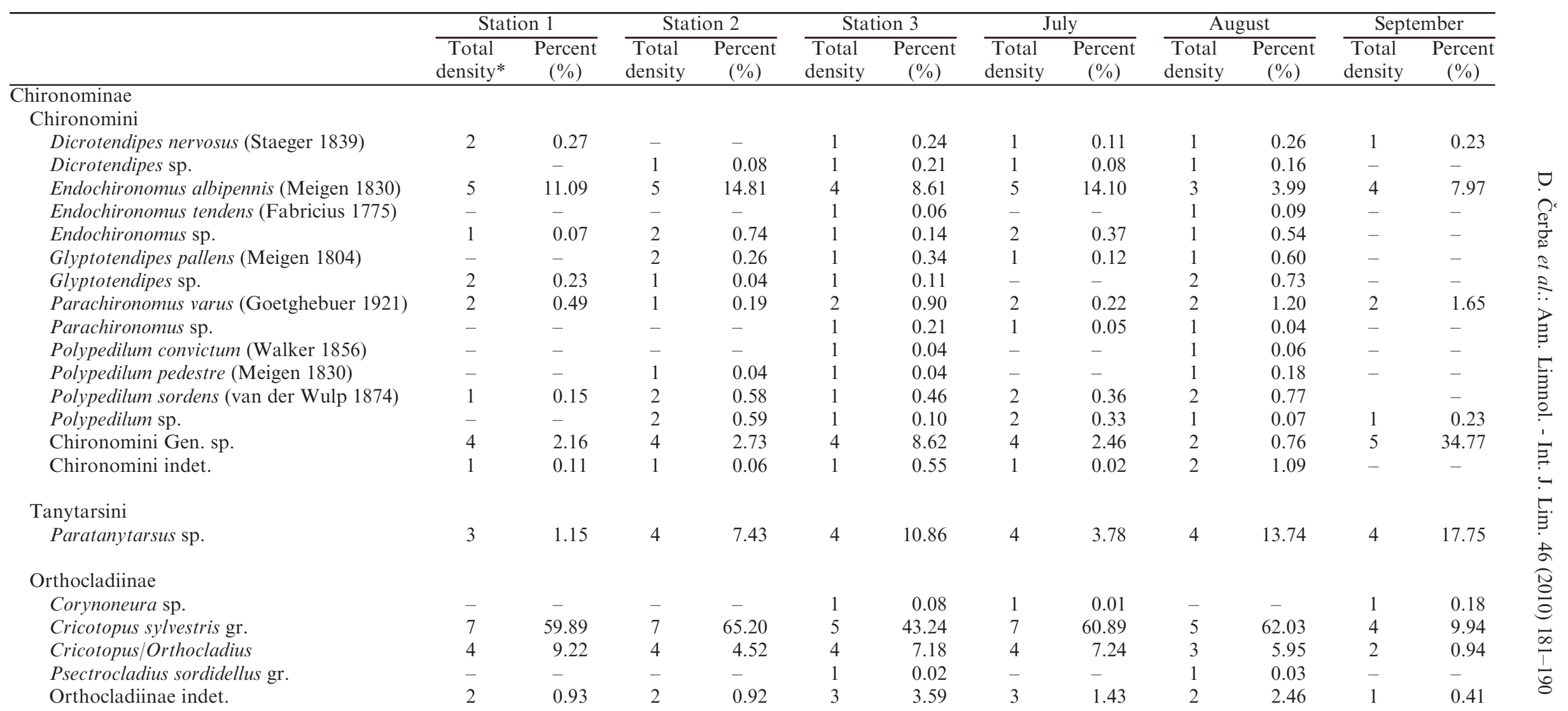

Tanypodinae

Tanypodinae indet.

0.07

0.20

Chironomidae indet. $5 \quad 14.24$ $\begin{array}{lll}1.72 & 4 & 14.40\end{array}$ $8.43 \quad 3 \quad 5.05$

*Total density key: 1: 1-100 ind.; 2: 101-500 ind.; 3: 501-1000 ind.; 4: 1001-5000 ind.; 5: 5001-10 000 ind.; 6: $10001-20000$ ind.; 7 : >20 000 ind. (ind. = number of individuals per $100 \mathrm{~g}$ macrophyte dry weight). 
Table 2. Biotic and abiotic variables in Lake Sakadaš in 2004.

\begin{tabular}{|c|c|c|c|c|c|c|}
\hline Physico-chemical variables & $\begin{array}{l}\text { Station I } \\
\text { min-max }\end{array}$ & $\begin{array}{l}\text { Station II } \\
\text { min-max }\end{array}$ & $\begin{array}{l}\text { Station III } \\
\text { min-max }\end{array}$ & $\begin{array}{c}\text { July } \\
\text { min-max }\end{array}$ & $\begin{array}{l}\text { August } \\
\text { min-max }\end{array}$ & $\begin{array}{c}\text { September } \\
\text { min-max }\end{array}$ \\
\hline Air temperature $\left({ }^{\circ} \mathrm{C}\right)$ & $16-29$ & $16.5-29$ & $17-31$ & $16-31$ & $23-28$ & $18.5-22$ \\
\hline Water temperature $\left({ }^{\circ} \mathrm{C}\right)$ & $21-27$ & $20.5-27$ & $22-27$ & $23-27$ & $23-25.5$ & $20.5-22.5$ \\
\hline Secchi depth (m) & $0.53-1.21$ & $0.23-1.17$ & $0.36-1.32$ & $0.7-1.32$ & $0.23-0.74$ & $0.38-0.63$ \\
\hline Dissolved oxygen concentration $\left(\mathrm{mg} . \mathrm{L}^{-1}\right)$ & $3.77-12.55$ & $3.6-12.03$ & $3.95-12.08$ & $3.6-5.27$ & $7.28-12.55$ & $8.39-11.62$ \\
\hline$a\left(\mu \mathrm{g} . \mathrm{L}^{-1}\right)$ & $14.26-57.83$ & $13.05-50.45$ & $8.63-56.82$ & $8.63-40.32$ & $24.53-50.45$ & $43.04-57.83$ \\
\hline Total phosphorus (mg. $\mathrm{L}^{-1}$ ) & $0.04-1.16$ & $0.07-0.15$ & $0.01-0.16$ & $0.08-0.16$ & $0.05-0.13$ & $0.01-1.16$ \\
\hline Dry biomass $(\mathrm{g})$ & $0.2-1.27$ & $0.37-1.33$ & $0.34-2.24$ & $0.3-1.35$ & $0.2-2.24$ & $0.82-1.48$ \\
\hline TSIChl $a$ & $56.7-70.4$ & $55.8-69.1$ & $51.7-70.2$ & $51.7-66.9$ & $61.9-69.1$ & $67.5-70.4$ \\
\hline TSITP & $58.1-105.8$ & $65.4-76.3$ & $35.8-77.3$ & $68.1-77.2$ & $61.7-74.2$ & $35.8-105.8$ \\
\hline
\end{tabular}

whereas Tanypodinae representatives were present on 12 August at station 2. The highest number of taxa was found on 18 August. Most larvae were mounted on slides, so the gut content was visible and its examination revealed the presence of filamentous green algae, Cosmarium sp., diatoms, detritus and remains of plant tissue. Substantial differences were not observed among the species.

\section{Statistical analysis}

Based on cluster analysis, the sampling period was divided into three main colonisation periods at a $60 \%$ threshold similarity. NMDS ordination confirmed this result. The first colonisation period included samples collected from 14 to 28 July (period A), the second from 28 July to 18 August (period B), and the third from 25 August to 8 September (period C). However, samples taken on 21 July at station 2 and 4 August at station 3 were somewhat separated (Fig. 2). For this reason these samples (21 July at station 2, 4 August at station 3) were excluded from SIMPER and ANOSIM analysis. The taxa identified by SIMPER are presented in Table 3. C. sylvestris gr. and Chironomidae indet. had the greatest influence on the similarity between colonisation periods. The greatest differences were seen between groups B and C, with an average dissimilarity of $47.21 \%$ (Table 3), Chironomini Gen. sp., Cricotopus/Ortholadius and C. sylvestris gr. contributing most to the differences. ANOSIM results confirmed statistically significant differences among periods. With Global $\mathrm{R}=0.681$, there was a statistically significant difference between colonization periods $\mathrm{A}$ and $\mathrm{C}(\mathrm{R}=$ $0.704 ; p<0.001)$ and $\mathrm{B}$ and $\mathrm{C}(\mathrm{R}=0.881 ; p<0.001)$, $A$ and $B$ differences $(R=0.581)$ were less significant.

Redundancy analysis (RDA) was carried out using the following abiotic variables: water temperature (T), Secchi depth (SD), depth (D), total phosphorus (TP), macrophyte dry weight (DW), chlorophyll $a$ and dissolved oxygen concentrations ( $\mathrm{Chl} a$ and $\mathrm{O}_{2}$ ). Influence of each environmental variable on species abundance is presented on RDA biplot (Fig. 3). The sum of all the canonical eigenvalues was 0.513 (total variance) and the total variance in species data for the first two axes was 25.5. Speciesenvironment correlations were 0.942 for axis 1 and 0.855 for axis 2. First axis was best defined by Secchi depth, macrophyte dry weight and depth (eigenvalue ax $1=0.139$ ) while the axis 2 was best defined by temperature and macrophyte dry weight (eigenvalue ax $2=0.116$ ). Monte Carlo permutation test indicated that all the axes were significant $(\mathrm{F}$-ratio $=1.502, p<0.014)$, and also that the species are significantly related to the tested set of environmental variables. On the right side of the plot most abundant species are positioned, including C. sylvestris and E. albipennis. Species Parachironomus sp. shows a good correlation with TP and E. albipennis with SD. DW and Chl $a$ positively correlate with Dicrotendipes sp., P. sordidellus and E. tendens on the left side of the plot while $\mathrm{O}_{2}$ correlated with Orthocladiinae indet. (Fig. 3).

\section{Discussion}

The values of the environmental variables were characteristic of eutrophic lakes with similar seasonal weather conditions. Water quality monitoring over the last decade has shown that Lake Sakadaš shifted from meso-eutrophy to hypertrophy (Vidaković et al., 2002; Bogut et al., 2003). Macrophyte appearance in 2004 could be explained by high amounts of nutrients brought in by flood waters or by sediment resuspension related to the inflow of flood water, and possible disturbances by tourist boats should also be taken into account. Peršić and Horvatić (unpublished data) recorded highest fluctuations of nitrates following flooding in April and June 2004, with a gradual decrease in nitrogen concentrations towards the edge of the floodplain. This decrease in $\mathrm{N}$ concentrations could be bound to the uptake of nitrogen by macrophytes (Hamilton and Lewis, 1987; Olde Venterink et al., 2003). Greater macrophyte biomass and higher $\mathrm{Chl} a$ concentrations at the end of the investigated period indicated an increased amount of periphyton and of available food for invertebrates as well as increase of the trophic state.

During the study, three Chironomidae subfamilies were recorded: Chironominae (Chironomini and Tanytarsini), Orthocladiinae and Tanypodinae. Tóth et al. (2008) also reported these three subfamilies of chironomids in phytophylus communities of a backwater of the Tisza River. The chironomid species found are characteristic of eutrophic lakes and macrophyte communities, including the dominance of C. sylvestris gr. (Darby, 1962; Menzie, 


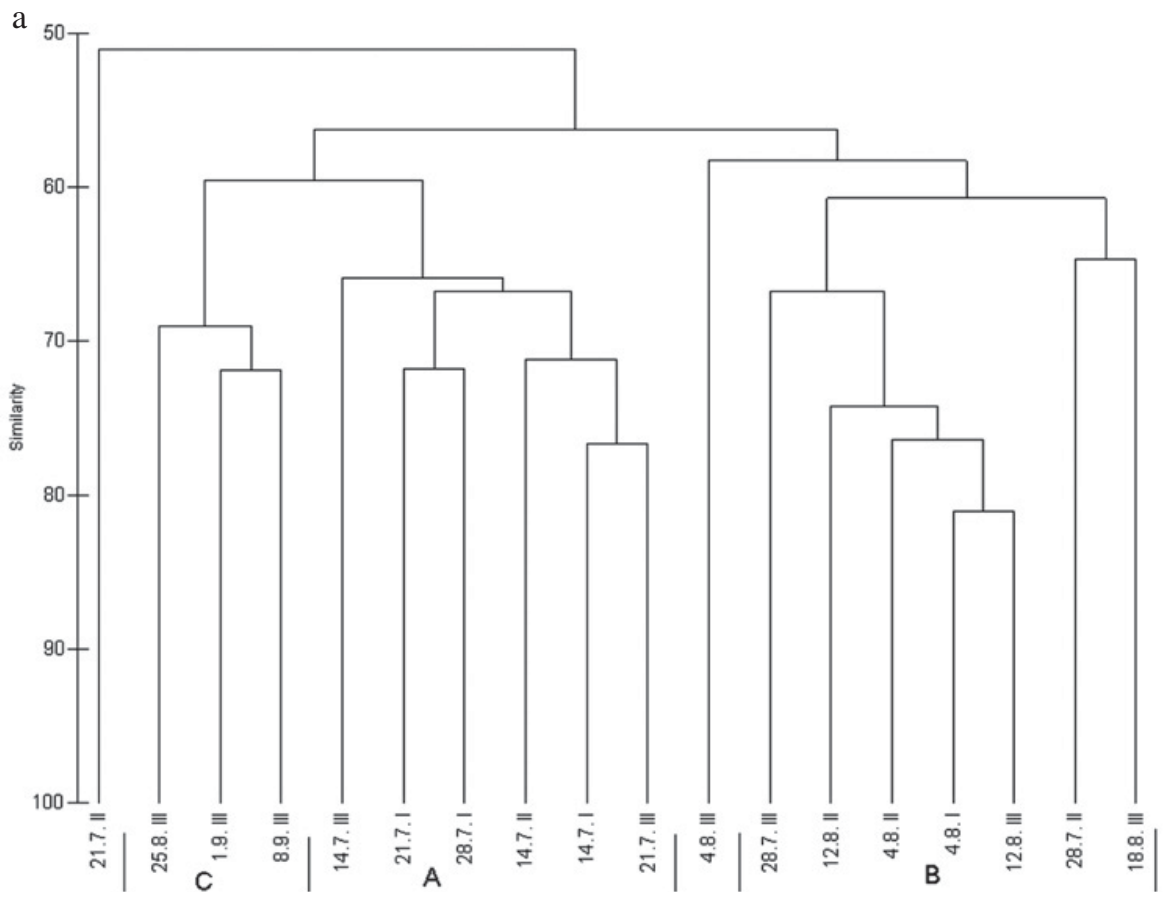

b

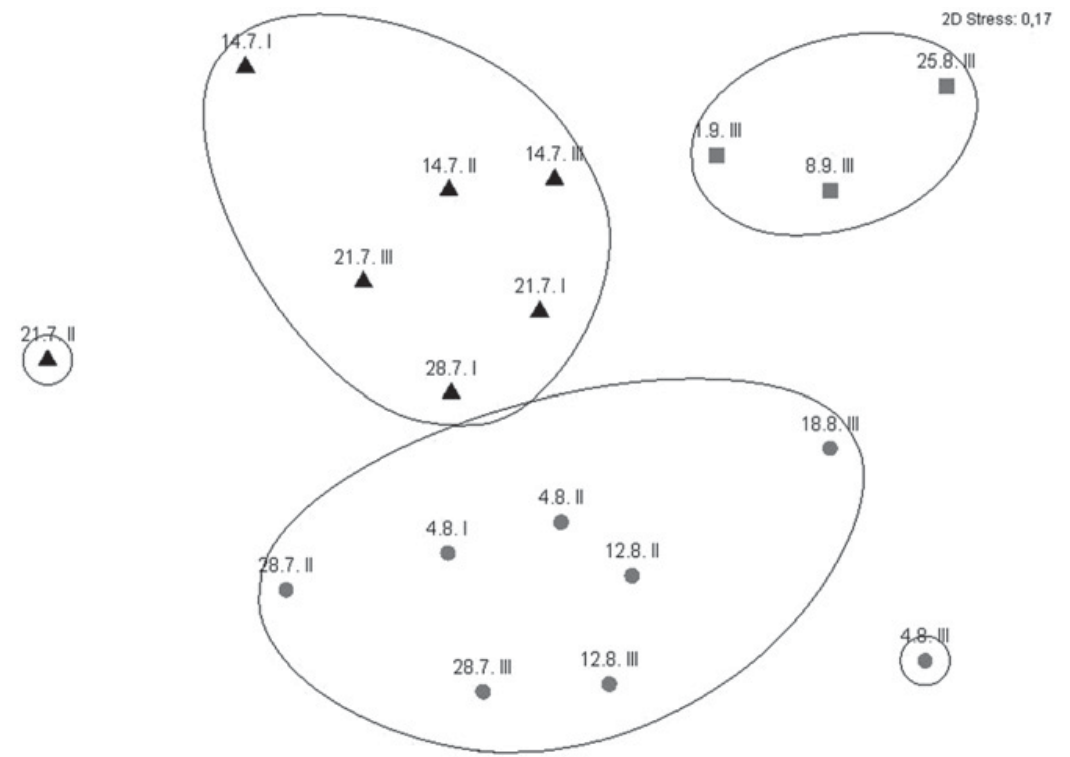

Fig. 2. a) Hierarchical classification of the sampling sites and dates based on the taxa abundance; b) non-metric multidimensional scaling (NMDS) of taxa abundance matrix data; samples of each colonisation period are labelled (similarity level of $60 \%$ ). $\Delta$ Colonization period A; O colonization period B; 1 colonization period $\mathrm{C}$.

1981; Armitage et al., 1995). Brodersen et al. (2001) found Cricotopus sp. and Glyptotendipes sp. to be characteristic of eutrophic and hypertrophic lakes, dominated by elodeids, characeans or characterized by the absence of aquatic plants. The large abundance of larvulae at the beginning of the study period was likely due to the start of colonization at station 2, while the second peak in September was a result of recolonization after emergence. The increase of the collector-filterer Paratanytarsus sp. in September could be explained by the increased amount of available food, either as developed periphyton or phytoplankton. There was not a clear explanation about the marked increase of chironomid abundance at station 2 on 21 July of the following species: E. albipennis, Polypedilum sordens (van der Wulp), C. sylvestris gr. and Paratanytarsus sp., not recorded at the other two sampling stations.

Macrophyte stands in Lake Sakadaš growed in late June and were sampled when reached a suitable size. Since the stands lasted for approximately three months, they can be considered a temporary habitat. NMDS ordination and 
Table 3. SIMPER results showing taxa contribution to similarities within, and dissimilarities between groups of samples identified using cluster and NMDS analysis.

\begin{tabular}{|c|c|c|c|c|c|c|}
\hline \multirow[b]{2}{*}{$\begin{array}{l}\text { Group } \\
\text { Taxa }\end{array}$} & \multicolumn{3}{|c|}{ Average similarity $\%$} & \multicolumn{3}{|c|}{ Average dissimilarity $\%$} \\
\hline & $\begin{array}{c}68.11 \\
\dot{A} \\
\text { Contrib. } \%\end{array}$ & $\begin{array}{c}66.48 \\
\text { B } \\
\text { Contrib. \% }\end{array}$ & $\begin{array}{c}69.98 \\
\stackrel{\mathrm{C}}{\mathrm{C}} \\
\text { Contrib. \% }\end{array}$ & $\begin{array}{c}40.90 \\
\mathrm{~A} \times \mathrm{B} \\
\text { Contrib. } \%\end{array}$ & $\begin{array}{c}40.44 \\
\mathrm{~A} \times \mathrm{C} \\
\text { Contrib. } \%\end{array}$ & $\begin{array}{c}47.21 \\
\mathrm{~B} \times \mathrm{C} \\
\text { Contrib. } \%\end{array}$ \\
\hline$\overline{\text { Cricotopus sylvestris gr. }}$ & 27.09 & 24.34 & 18.62 & 7.25 & 14.95 & 9.31 \\
\hline Cricotopus/Ortholadius & 20.22 & 13.03 & - & 5.12 & 17.21 & 10.04 \\
\hline Endochironomus albipennis & 17.04 & 11.56 & 13.78 & 7.49 & 8.66 & 3.08 \\
\hline Chironomidae indet. & 16.35 & 8.30 & 20.49 & 8.59 & 7.30 & 6.54 \\
\hline Paratanytarsus sp. & 9.22 & 16.78 & 14.21 & 5.76 & 7.45 & 4.84 \\
\hline Parachironomus varus & - & 2.42 & 12.48 & - & 9.53 & 4.67 \\
\hline Chironomini Gen. sp. & - & - & 16.75 & 10.06 & 9.06 & 12.49 \\
\hline Orthocladiinae indet. & - & 9.00 & - & 9.93 & 4.80 & 8.85 \\
\hline Glyptotendipes pallens & - & - & - & 4.65 & - & 4.44 \\
\hline Chironomini indet. & - & 4.09 & - & 5.58 & - & 5.75 \\
\hline Dicrotendipes nervosus & - & - & - & - & 6.47 & 4.91 \\
\hline Polypedilum sordens & - & - & - & 4.73 & 2.99 & 4.02 \\
\hline Glyptotendipes sp. & - & 2.33 & - & 4.57 & - & 4.39 \\
\hline Polypedilum sp. & - & - & - & 3.54 & 4.27 & 4.19 \\
\hline Dicrotendipes sp. & - & - & - & 4.37 & - & - \\
\hline Endochironomus sp. & - & - & - & 3.94 & - & 3.49 \\
\hline Parachironomus sp. & - & - & - & - & - & - \\
\hline
\end{tabular}

cluster analysis separated three main colonization periods based on larval abundance. The abundance of $C$. sylvestris gr. was highest during the first colonisation period, lower in the second period and then dropped significantly at the end of the season, possibly due to adult emergence or to an increase in the amount of periphyton covering the macrophyte surface or to a competition with other periphyton grazers. C. sylvestris is an ubiquitous species, classified by Darby (1962) as an obligate phytophage, and some authors (McRae et al., 1990; Cuda et al., 2002) consider Cricotopus species as possible control agents for several plant species. Menzie (1981) recorded the dominance of C. sylvestris in a Myriophyllum stand with up to $80 \%$ of all recorded chironomid larvae. Balci and Kennedy (2003) found $C$. sylvestris as the second most dominant species on $M$. spicatum, with a maximum abundance in May, a sharp decline at the end of May and in early June, and disappearance in mid June. C. sylvestris seems to be a good colonizer. Species with such a short larvae stage typically have the ability to colonize "clean" substrates and can play an important role in forming the "primary" midge community in short-lived temporary habitats (Wotton et al., 1992). In the third colonisation period, members of the tribe Chironomini dominated on Myriophyllum stands. They require the development of an organic coating on the substratum before their larvae can colonize. A similar observation was noted by Wotton et al. (1992) in a temporary habitat of sand filter beds. The second most abundant species was E. albipennis. This bivoltine species is phytophylous and commonly found in eutrophic lakes (Harrison and Hildrew, 1998; Brodersen et al., 2001; Kumari et al., 2007). E. albipennis is known to be feeding on detritus or macrophyte tissue (Armitage et al., 1995; Kornijów et al., 1995) while Walsh (1951) determined it's ability to filter-feed even when oxygen concentration is low.

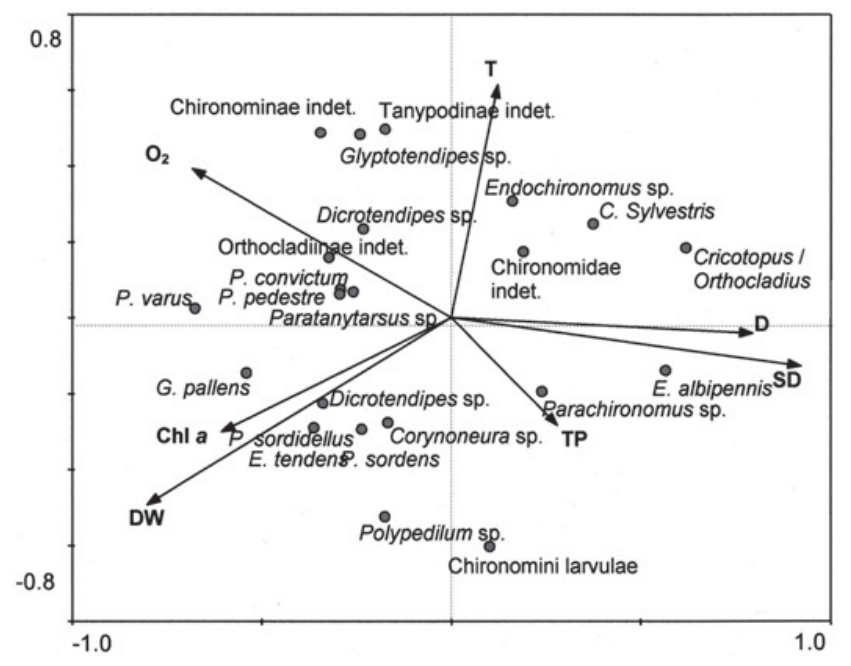

Fig. 3. RDA ordination biplot indicating influence of environmental variables on chironomid species. Arrows represent environmental variables distribution, circles represent chironomid species. SD - Secchi depth; D - depth; T - water temperature; DW - macrophyte dry weight; $\mathrm{O}_{2}$ - oxygen concentration; Chl $a$-chlorophyll $a$ concentration.

Chironomids are primarily opportunistic omnivores and can change their diet depending on the age, season or available food (Armitage et al., 1995). Although this was not the primary aim of this study, inspection of stomach contents indicated various feeding habits. The algae found in larval guts were mostly represented by filamentous green algae, Cosmarium sp. and diatoms. However, material appearing to be detritus and plant tissue was also observed. Cosmarium can be preferred among other available food due to its larger cell size (Botts and Cowell, 1992). According to Armitage et al. (1995), the most commonly reported food found in chironomid gut content 
is detritus. Snails can be competitors with midges for periphyton as a food source, but their very low abundance (less than 0.5\%) in M. spicatum stands (Cerba et al., 2009) could be a reason for the high abundance of chironomids. It is possible that food supplies have a greater importance over the physical and chemical traits of the water column for the Cricotopus genus, as reported by Dvoràk (1996) who found a strong positive correlation between the abundance of Cricotopus and diatom biomass on the surface of aquatic macrophytes. Pieczyńska et al. (1999), on the other hand, found that trophic status can be more important than food. Meanwhile, Marques et al. (1999) found the genus Cricotopus at stations with varying trophic status and impact levels, indicating that its distribution cannot be primarily associated with water quality. The eutrophic (hypertrophic) water bodies of Kopački Rit support chironomids in high numbers (Bogut et al., 2007; Cerba et al., 2009). In addition to being a food source (tissue or periphyton), plants are also used by chironomids and other invertebrates as shelter from predators, either vertebrate or invertebrate (Diehl, 1992; Prejs et al., 1997).

According to RDA analysis, Secchi depth, macrophyte dry weight, depth and water temperature were the variables exerting the main influence on abundance of the most abundant chironomid species. Water temperature has a very important role in the life cycle and behaviour of chironomids - egg development, pupal stages and emergence, and larvae (Menzie, 1981; Rossaro, 1991; Armitage et al., 1995). One generation of $C$. sylvestris could be completed in less than one month at high temperatures (Rossaro, 1987a, 1987b). Also, temperature influences different processes in the lake, which in turn can have an indirect influence on the chironomid community (Królikowska et al., 1998; Květ and Westlake, 1998; Brooks et al., 2007). Thorp and Chesser (1983) found that the main factors influencing chironomid density and diversity in a South Carolina reservoir were plant biomass and temperature. The importance of suspended particles as a possible food source within the water column explains the significant correlation of Secchi depth with chironomid fauna abundance. Distribution of Chl $a$ concentration and Cricotopus representatives on the RDA plot indicates negative impact of the increase of trophic state on early colonizers. RDA also indicated that macrophyte dry biomass was important environmental variable. Some authors found a positive relationship between macrophytes and chironomid abundance and diversity, but also suggested the importance of plant architecture (Soszka, 1975; Cheruvelil et al., 2002; Kuczyńska-Kippen, 2007).

\section{Conclusions}

Three M. spicatum stands represented temporal habitat in the lake. The chironomid species abundance composition was characteristic for phytophylous communities in eutrophic lakes and was mostly influenced by Secchi depth, macrophyte dry weight, depth and water temperature. The sampling season was divided into three colonization periods. There was also a temporal difference in the chironomid community structure and abundance, indicating that $C$. sylvestris gr. is a good colonizer of temporal habitats. The dominance of $C$. sylvestris gr. in this study confirms the importance of this species group within M. spicatum stands as emphasized by many authors in the past.

Acknowledgements. The authors would like to thank the anonymous reviewers for their useful comments. Also, we are very thankful to Dr. Ladislav Hamerlik for assistance with determination problems and Dr. Ivancica Ternjej for valuable comments on earlier drafts of manuscript. Special thanks to Dubravka Špoljarić and MSc Filip Stević. This study was supported by the Ministry of Science, Education and Sports of the Republic of Croatia (project no. 0122009).

\section{References}

APHA, 1985. Standard methods for examination of water and wastewater, American Public Health Association, 16th Edition, Washington, $1268 \mathrm{p}$.

Armitage P.D., Cranston P.S. and Pinder L.C.V., 1995. The Chironomidae: Biology and ecology of nonbiting midges, Chapman and Hall, London, 572 p.

Balci P. and Kennedy J.H., 2003. Comparison of chironomids and other macroinvertebrates associated with Myriophyllum spicatum and Heteranthera dubia. J. Freshwater Ecol., 18, 235-247.

Bitušík P., Svitok M., Kološta P. and Hubková M., 2006. Classification of the Tatra Mountain lakes (Slovakia) using chironomids (Diptera, Chironomidae). Biologia, 61, 191-201.

Bogut I., Vidaković J. and Palijan G., 2003. Trophic state and water quality in Kopački rit during 2002. In: Gereš D. (ed.), Croatian waters in 21st century: Proceedings of the 3rd Croatian Conference on Waters, Croat. Waters, 173-180.

Bogut I., Vidaković J., Palijan G. and Čerba D., 2007. Benthic macroinvertebrates associated with four species of macrophytes. Biologia, 62, 600-606.

Bogut I., Vidaković J., Čerba D. and Palijan G., 2009. Epiphytic meiofauna in stands of different submerged macrophytes. Ekoloji, 70, 1-9.

Bogut I., Čerba D., Vidaković J. and Gvozdić V., 2010. Interactions of weed-bed invertebrates and Ceratophyllum demersum L. stands in a floodplain lake. Biologia, 65, 113-121.

Botts P.S. and Cowell B.C., 1992. Feeding selectivity of two species of epiphytic chironomids in a subtropical lake. Oecologia, 89, 331-337.

Brodersen K.P., Odgaard B., Vestergaard O. and Anderson N.J., 2001. Chironomid stratigraphy in the shallow and eutrophic Lake Søbygaard, Denmark: Chironomid-Macrophyte cooccurrence. Freshwater Biol., 46, 253-267.

Brooks S.J., Langdon P.G. and Heiri O., 2007. The identification and use of palaearctic Chironomidae larvae in palaeoecology. QRA Technical Guide, 10, 276 p.

Carlson R.E. and Simpson J., 1996. A coordinator's guide to volunteer lake monitoring methods, North American Lake Management Society, 96 p. 
Cheruvelil K.S., Soranno P.A., Madsen J.D. and Roberson M.J., 2002. Plant architecture and epiphytic macroinvertebrate communities: the role of an exotic dissected macrophyte. J. N. Am. Benthol. Soc., 21, 261-277.

Clarke K.R. and Gorley R.N., 2006. PRIMER v6: User manual/ tutorial, PRIMER-E, Plymouth, 92 p.

Cranston P.S., 1982. A key to the larvae of the British Orthocladiinae (Chironomidae). Freshw. Biol. Assoc. Sc. Publ., 45, 152 p.

Cuda J.P., Coon B.R., Dao Y.M. and Center T.D., 2002. Biology and laboratory rearing of Cricotopus lebetis (Diptera: Chironomidae), a natural enemy of the aquatic weed hydrilla (Hydrocharitaceae). Ann. Entomol. Soc. Am., 95, 587-596.

Čerba D., Bogut I., Vidaković J. and Palijan G., 2009. Invertebrates in Myriophyllum spicatum L. stands in Lake Sakadaš, Croatia. Ekologia, 28, 94-105.

Darby R.E., 1962. Midges associated with California rice fields, with special reference to their ecology (Diptera: Chironomidae). Hilgardia, 31, 1-206.

Dévai G., 1990. Ecological background and importance of change of chironomid fauna (Diptera: Chironomidae) in shallow Lake Balaton. Hydrobiologia, 191, 189-198.

Diehl S., 1992. Fish predation and benthic community structure: The role of omnivory and habitat complexity. Ecology, 73, 1646-1661.

Dvořák J., 1996. An example of relationship between macrophytes, macroinvertebrates and their food resources in a shallow eutrophic lake. Hydrobiologia, 339, 27-36.

Frouz J., Matěna J. and Ali A., 2003. Survival strategies of chironomids (Diptera: Chironomidae) living in temporary habitats: a review. Eur. J. Entomol., 100, 459-465.

Hamerlík L. and Bitušík P., 2009. The distribution of littoral chironomids along an altitudinal gradient in High Tatra Mountain lakes: Could they be used as indicators of climate change? Ann. Limnol. - Int. J. Lim., 45, 145-156.

Hamerlík L. and Brodersen K.P., 2010. Non-biting midges (Diptera: Chironomidae) from fountains of two European cities: micro-scale island biogeography. Aquat. Insects, 32, $67-79$.

Hamilton S.K. and Lewis W.M., 1987. Causes of seasonality in the chemistry of a lake on the Orinoco River floodplain, Venezuela. Limnol. Oceanogr., 32, 1277-1290.

Hann B.J., 1995. Invertebrate associations with submersed aquatic plants in a prairie wetland. UFS (Delta Marsh) Annual Report, 30, 78-84.

Harrison S.S.C. and Hildrew A.G., 1998. Patterns in the epilithic community of a lake littoral. Freshwater Biol., 39, 477-492.

Kornijów R., Gulati R.D. and Ozimek T., 1995. Food preference of freshwater invertebrates: comparing fresh and decomposed angiosperm and a filamentous alga. Freshwater Biol., 33, 205-212.

Królikowska J., Přibáň K. and Šmíd P., 1998. Micro-climatic conditions and water economy of wetlands vegetation. In: Westlake D.F., Květ J. and Szczepański A. (eds.), The Production Ecology of Wetlands, Cambridge University Press, Cambridge, 367-404.

Kuczyńska-Kippen N., 2007. Habitat choice in rotifera communities of three shallow lakes: impact of macrophyte substratum and season. Hydrobiologia, 593, 27-37.

Kumari M., Kangur K. and Haldna M., 2007. Variation of macrozoobenthos communities in the reed Phragmites australis belt of two large shallow lakes. Proc. Estonian Acad. Sci. Biol. Ecol., 56, 141-153.

Květ J. and Westlake D.F., 1998. Primary production in wetlands. In: Westlake D.F., Květ J. and Szczepański A. (eds.), The Production Ecology of Wetlands, Cambridge University Press, Cambridge, 78-168.

Langdon P.G., Ruiz Z., Brodersen K.P. and Foster I.D.L., 2006. Assessing lake eutrophication using chironomids: understanding the nature of community response in different lake types. Freshwater Biol., 51, 562-577.

Marques M.M.G.S.M., Barbosa F.A.R. and Calisto M., 1999. Distribution and abundance of Chironomidae (Diptera, Insecta) in an impacted watershed in South-east Brazil. Rev. Bras. Biol., 59, 553-561.

McRae I.V., Winchester N.N. and Ring R.A., 1990. Feeding activity and host preference of milfoil midge, Cricotopus myriophylli Oliver (Diptera: Chironomidae). J. Aquat. Plant. Manage., 28, 89-92.

Menzie C.A., 1980. The Chironomid (Insecta: Diptera) and other fauna of a Myriophyllum spicatum L. plant bed in the lower Hudson River. Estuaries, 3, 38-54.

Menzie C.A., 1981. Production ecology of Cricotopus sylvestris (Fabricius) (Diptera: Chironomidae) in a shallow estuarine cove. Limnol. Oceanogr., 26, 467-481.

Mihaljević M., Stević F., Horvatić J. and Hackenberger Kutuzovic B., 2009. Dual impact of the flood pulses on the phytoplankton assemblages in a Danubian floodplain lake (Kopački Rit Nature Park, Croatia). Hydrobiologia, 617, 77-88.

Mihaljević Z., Kerovec M., Tavčar V. and Bukvić I., 1998. Macroinvertebrate community on an artificial substrate in the Sava River: long-term changes in the community structure and water quality. Biologia, 53, 611-620.

Mihaljević Z., Tavčar V., Kerovec M. and Bukvić I., 2000. Vertical distribution of Chironomidae larvae in the karstic travertine barrage Lake Visovac (Croatia). In: Hoffrichter O. (ed.), Late 20th century research on Chironomidae: an anthology from the 13th International symposium on Chironomidae, Berichte aus der Biologie, Shaker Verlag, Aachen, 325-333.

Mihaljević Z., Kerovec M., Ternjej I. and Popijač A., 2004. Long-term changes in the macroinvertebrate community structure of a shallow Mediterranean lake. Ekologia, 23, 421-429.

Nazarova L.B., Riss H.W., Kahlheber A. and Werding B., 2004. Some observations of buccal deformities in chironomid larvae (Diptera: Chironomidae) from the Ciénaga Grande de Santa Marta, Colombia. Caldasia, 26, 275-290.

Olde Venterink H., Hummelink E. and den Hoorn M.W., 2003. Denitrification potential of a river during flooding with nitrate-rich water: grasslands versus reedbeds. Biogeochem., $65,233-244$.

Palijan G. and Fuks D., 2006. Alternation of factors affecting bacterioplankton abundance in the Danube River floodplain (Kopački Rit, Croatia). Hydrobiologia, 560, 405-415.

Peršić V., Čerba D., Bogut I. and Horvatić J., to appear. Trophic state and water quality in the Danube floodplain lake (Kopački Rit Nature Park, Croatia) in relation to hydrological connectivity. In: Ansari A.A., Singh S. and Lanza Guy R. (eds.), Eutrophication: Causes, Consequences and Control, Springer (in press). 
Pieczyńska E., Kołodziejczyk A. and Rybak J.I., 1999. The responses of littoral invertebrates to eutrophicationlinked changes in plant communities. Hydrobiologia, 391, 9-21.

Prejs A., Koperski P. and Prejs K., 1997. Food-web manipulation in small, eutrophic Lake Wirbel, Poland: the effect of replacement of key predators on epiphytic fauna. Hydrobiologia, 342/343, 377-381.

Punti M., Rieradevall M. and Prat N., 2007. Chironomidae assemblages in reference condition Mediterranean streams: environmental factors, seasonal variability and ecotypes. Fundam. Appl. Limnol. (Arch. Hydrobiol.), 170, 149-165.

RAMSAR, 2005. The list of wetlands of international importance, The Secretariat of the Convention on Wetlands, Gland, $36 \mathrm{p}$.

Rieradevall M. and Brooks S.J., 2001. An identification guide to subfossil Tanypodinae larvae (Insecta: Diptera: Chironomidae) based on cephylic setation. J. Paleolimnol., $25,81-99$.

Rossaro B., 1987a. Chironomid emergence in the Po river (Italy) near a nuclear power plant. Entomologica Scandinavica, Suppl., 29, 331-338.

Rossaro B., 1987b. Insect emergence in a stretch of the Po river (Italy). Arch. Hydrobiol., 109, 245-256.

Rossaro B., 1991. Chironomids and water temperature. Aquat. Insects, 13, 87-98.

Schmid P.E., 1993. A key to the larval Chironomidae and their instars from Austrian Danube Region streams and rivers, Part I: Diamesinae, Prodiamesinae and Orthocladiinae. Wasser und Abwasser, Suppl., 3, 514 p.

Soszka G.J., 1975. The invertebrates on submersed macrophytes in three Masurian lakes. Ekol. Pol., 23, 271-391.

Streble H. and Krauter D., 2002. Das Leben im Wassertropfen. Mikroflora und Mikrofauna des Suswassers, Kosmos, Stutgart, 358 p.

Tavčar V., 1988. Populations of the larvae of Chironomidae (Diptera) in biocenoses of benthos and periphyton of some streams in Psunj and Papuk mountains. Biosistematika, 14, 31-41. (In Croatian, English summary.)

Tavčar V., 1993. Chironomid (Diptera) larvae of the Butoniga Reservoir, Istria, Croatia, and its feeder rivers. Hydrobiologia, 262, 89-96.

ter Braak C.J. and Šmilauer P., 2002. CANOCO reference manual and CanoDraw for Windows User's Guide: Software for Canonical Community Ordination (version 4.5), Microcomputer Power (Ithaca, NY, USA), 500 p.

Thorp J.H. and Chesser R.K., 1983. Seasonal responses of lentic midge assemblages to environmental gradients. Holoarctic Ecol., 6, 123-132.

Tóth M., Móra A., Kiss B. and Dévai G., 2008. Chironomid communities in different vegetation types in a backwater Nagy-Morotva of the active floodplain of river Tisza, Hungary. Bol. Mus. Mun. Funchal, 13, 169-175.

Vidaković J. and Bogut I., 2007. Periphyton nematode assemblages in association with Myriophyllum spicatum L. in Lake Sakadaš Croatia. Russ. J. Nematol., 15, 79-88.

Vidaković J., Bogut I., Borić E. and Zahirović Ž., 2002. Hydrobiological research in the Kopački Rit Nature Park in the period November 1997 - October 2001. Croat. Waters, $10,127-144$

Vidaković J., Palijan G. and Čerba D., to appear. Relationship between nematode community and biomass and composition of periphyton developing on artificial substrates in floodplain lake. Pol. J. Ecol.

Walsh B.M., 1951. The function of haemoglobin in relation to filter feeding in leaf-mining chironomid larvae. J. Exp. Biol., $28,57-61$.

Wiederholm T. (ed.), 1983. Chironomidae of the Holarctic region, Keys and diagnoses. Part I: Larvae. Ent. Scand., Suppl., 19, 1-457.

Wotton R.S., Armitage P.D., Aston K., Blackburn J.H., Hamburger M. and Woodward C.A., 1992. Colonization and emergence of midges (Chironomidae: Diptera) in slow sand filter beds. Neth. J. Aquat. Ecol., 26, 331-339. 